\title{
The Effects of Instructional Leadership and Organizational Culture on Teacher Performance at Public Senior High Schools in Sleman Regency, Indonesia
}

\author{
Banu Widiasmara ${ }^{1}$, Dwi Esti Andriani ${ }^{2}$ \\ (bwidiasmara@gmail.com¹, dwi_esti@uny.ac.id² \\ Educational Management Study Program, Graduate School, Universitas Negeri Yogyakarta, \\ Indonesia ${ }^{1}$, Educational Management Study Program, Graduate School, Universitas Negeri Yogyakarta, \\ Indonesia $^{2}$
}

\begin{abstract}
This study aims to examine whether principal instructional leadership and organizational culture have effects on teacher performance separately and simultaneously. This ex-post facto quantitative research was conducted at several public senior high schools located in Sleman regency, Indonesia. The sample of this study was collected from 244 teachers who were selected using a proportionate random sampling technique. A valid and reliable questionnaire was developed to collect the data which were then analyzed quantitatively using the SPPS version 20. The results show that instructional leadership of the principals and organizational culture significantly influence teacher performance separately and simultaneously.
\end{abstract}

Keywords: Instructional Leadership, Organizational Culture, Teacher Performance.

\section{Introduction}

High quality of education requires teachers with high performance. They are teachers who are always motivated to improve their ability to plan, implement, and assess learning [1]. The level of teacher performance is influenced by many factors [2]-[4]. Two of them are principal instructional leadership and organizational culture.

Instructional leadership involves activities carried out by a school principal to improve the quality of learning processes and student learning achievement [5]-[7]. This leadership affects student achievement indirectly and is mediated by the teachers [8]. A study conducted by Sukmawati and Herawan in Indonesia shows that there is a positive and significant influence $(64 \%)$ of principal instructional leadership on teacher performance [9].

Organizational culture also has a significant effect on teacher performance [10]. The culture is a repetitive habit that serves as the value and lifestyle of people within an organization [10][12]. Organizational culture will influence the behavior of organization members leading to the achievement of organization goals [3]. Pastin states that it is definite that a strong culture underlies people's beliefs, behaviors, and ways of doing things because culture and tradition are closely correlated [13].

Performance is the outcome of physical and non-physical work [14]. Performance is the result of work achieved by employees as they complete assigned tasks and fulfill responsibilities 
[15]. Khine et al. in Yuliejatiningsih argue that teacher performance is a means of carrying out the teacher's main task which is teaching [16]. In line with it, teacher performance is the ability to plan, implement, and assess learning both related its process and results [1].

Planning lessons includes activities to formulate what will be done to facilitate student learning activities, how to do it, and what students will achieve [1]. The result is the lesson plan. It presents the procedures and organization of learning to achieve competencies that are defined in the national standard of content and syllabus [2].

Implementation of learning begins with attracting student attention and providing stimulus to prepare the students mentally [1]. When learning takes place, teachers are required to be creative so that students learn according to the plan prepared. Teachers should be able to decide whether teaching and learning activities should be terminated, or the teaching method should be changed. They also need to be aware of the needs to repeat the explanation of previous lessons when students do not achieve the learning objectives set. In addition, teachers should obviously master the lesson materials [17].

Before ending a lesson, teachers should conduct an evaluation as well as provide feedback and reinforcement. Evaluation of learning outcomes is carried out to determine the level of student understanding and ability. It finds out how well the material is delivered and whether the students have mastered the materials presented. Accordingly, the results can be used to improve the quality of learning [1].

Leadership is the act of influencing others to achieve expected goals [18]-[20]. Leadership is also defined as a social process to achieve common goals in groups [21]. In line with it leadership is a social process in which an individual or group influences other people's behaviors to achieve common goals [22].

Instructional leadership is one of the principal leadership models. This model is believed to be effective in improving student learning achievement [8]. It provides indirect effects, mediated by the teachers. Research shows that instructional leadership has a significant effect on teacher performance [9]. The most popular model of instructional leadership is developed by Hallinger and Murphy. This model suggests three dimensions of leadership behavior, namely: defining the school mission, managing the instructional program, and developing the school learning climate [23].

This dimension refers to the role of principals in allocating certain resources in some periods of time, for example in one academic year. School principals as the instructional leaders ensure that schools have clear, measurable, and achievable goals by focusing on the student academic progress and communicating the goals to school teachers, administrative staff, and students [24].

This aspect refers to the principal's role in coordinating and controlling curriculum and learning [25]-[27]. This role requires the principal to make formal and informal class visits and provide feedback on teaching practices. When supervising and evaluating teaching, the principal ensures that learning leads to the goals determined [28]-[30].

The third element refers to the role of the principal in creating a conducive situation for teachers and students to be productive in learning and improving school quality [31]. Principals should organize student learning hours, develop teacher professionalism, provide high visibility, and give rewards to teachers and students for their achievements [24].

Organizational culture is a set of shared assumptions of people in an organization. This culture determines how organizational members perceive, think, and react to their environment. It also reflects the values and norms that serve as the vision and mission of the organization in order to achieve its goals. It is further explained that organizational culture can give members an organizational identity, facilitate collective commitment, create social system stability, and shape behavior by helping its members understand their surroundings [32]. 
Organizational culture provides cultural forms such as symbols, languages, narratives, and activities that highlight values and norms that somehow improve the members' sense of belonging to the organization and help give meaning to the organization activities [33]. Organizational culture, therefore, can help organizations maintain the performance of organizational members which in turn will support organizational performance [34]. Many experts suggest dimensions of organizational culture that can be used as an assessment instrument. Four dimensions of organizational culture that have been widely usaed, namely involvement, consistency, adaptation, and mission [35].

Involvement is a treatment that makes staff feel involved in the decision-making process so that they have a sense of responsibility for what is done [35], [36]. Involvement consists of three main indicators, namely empowerment, team orientation, and capability development [37]. Consistency is the agreement among organizational members on the basic assumptions and core values of the organization [13], [36]. Consistency is measured from the staff commitment to the organization. It is also related to what to do and what not to do. Consistency is a dimension that maintains the strength and stability of the organization [35], [37]. Adaptability is an organization's ability to transform environmental influences on the organization by making organizational internal changes [36]. The changes allow the organization to develop and grow. The ability to adapt can be measured by three indicators, namely creating change, customer focus, and organizational learning [35]. Mission is a cultural dimension that shows the main goals of the organization. A mission makes organization members more united and focused on what the organization considers important [36]. If an organization's mission is weak, staff will have no clue of short-term and long-term goals to be achieved [37]. Three indicators of good missions are well defined and clear strategies, goals, and visions.

\section{Method}

\subsection{Research Design and Setting}

This is a quantitative study that approaches phenomena objectively and then analyze them quantitatively [38]. It employed the ex post facto design that examined the correlation between programs and existing activities without manipulation or treatment.

\subsection{Research Population and sample}

This study was conducted in 17 public senior high schools located in Sleman Regency. The data were collected in three months, from June to August 2020. The participants of this study were 626 teachers with various educational backgrounds, positions, and ranks. The sample was selected using the proportionate random sampling technique. The sample was calculated using the following formula.

$$
\mathrm{n}=\frac{N}{1+N(e)^{2}}
$$

Information :

$\mathrm{n} \quad=$ Size of sample/number of respondents

$\mathrm{N} \quad=$ Size of population

$\mathrm{e} \quad=$ error rate of $5 \%$

Applying the formula above, the total number of the sample from the studied schools is: 


$$
\begin{aligned}
n & =\frac{626}{1+626(0,05)^{2}} \\
& =\frac{626}{1+626 \times 0,0025} \\
& =\frac{626}{2,565}=244
\end{aligned}
$$

Then, each school sample size was calculated using the Proportionate Random Sampling formula below:

$$
\mathbf{N}=\frac{x}{S} \times n
$$

Description

$\mathrm{N} \quad$ : Number of samples of each school

$\mathrm{X} \quad$ : Number of samples of each school

S : Total population of all schools

\begin{tabular}{|c|c|c|c|c|}
\hline No & School name & $\begin{array}{c}\text { Total number of } \\
\text { teachers }\end{array}$ & calculation & $\begin{array}{c}\text { Number of } \\
\text { Respondents }\end{array}$ \\
\hline 1 & SMAN 1 DEPOK & 42 & $\frac{42}{626} \times 244$ & 16 \\
\hline 2 & SMAN 1 MLATI & 35 & $\frac{35}{626} \times 244$ & 14 \\
\hline 3 & SMAN 1 NGAGLIK & 44 & $\frac{44}{626} \times 244$ & 17 \\
\hline 4 & SMAN 2 NGAGLIK & 45 & $\frac{45}{626} \times 244$ & 18 \\
\hline 5 & SMAN 1 GAMPING & 28 & $\frac{28}{626} \times 244$ & 9 \\
\hline 6 & SMAN 1 KALASAN & 51 & $\frac{51}{626} \times 244$ & 20 \\
\hline 7 & SMAN 1 SLEMAN & 47 & $\frac{47}{626} \times 244$ & 18 \\
\hline 8 & SMAN 2 SLEMAN & 31 & $\frac{33}{626} \times 244$ & 13 \\
\hline 9 & SMAN 1 PRAMBANAN & 46 & $\frac{46}{626} \times 244$ & 18 \\
\hline
\end{tabular}

n : Sample size/tottal respondents

Using the above formula, the total sample of each school is presented in the table below.

Table 1. Research Sample Data 


\begin{tabular}{llccc}
\hline 10 & SMAN 1 GODEAN & 41 & $\frac{41}{626} \times 244$ & 16 \\
11 & SMAN 1 TEMPEL & 25 & $\frac{25}{626} \times 244$ & 10 \\
12 & SMAN 1 PAKEM & 28 & $\frac{28}{626} \times 244$ & 11 \\
13 & SMAN 1 NGEMPLAK & 31 & $\frac{31}{626} \times 244$ & 12 \\
14 & SMAN 1 SEYEGAN & 46 & $\frac{46}{626} \times 244$ & 18 \\
15 & SMAN 1 MINGGIR SLEMAN & 27 & $\frac{27}{626} \times 244$ & 11 \\
16 & SMAN 1 CANGKRINGAN & 33 & $\frac{33}{626} \times 244$ & 13 \\
17 & SMAN 1 TURI & 26 & $\frac{26}{626} \times 244$ & 10 \\
\hline
\end{tabular}

\subsection{Operational Variable Definition}

Instructional leadership refers to principal behaviors to improve the quality of learning processes and student learning achievement as measured from three dimensions, namely defining the school mission, managing the instructional program, and developing the school learning climate to improve the quality of student learning processes and outcomes. Organizational culture refers to a combination of values, norms, beliefs, and expectations that are used as guidelines by people within an organization. This point includes the dimensions of involvement, consistency, adaptability, and mission. Teacher performance refers to the ability to complete their main tasks and responsibilities, namely planning, implementing, and assessing learning.

\subsection{Research instrument}

The instrument used in this study was a closed-ended questionnaire. The questionnaire validity and reliability were empirically measured before the questionnaires were distributed to 30 randomly selected teachers from several public senior high schools in Sleman Regency. The instrument validity was measured using the product-moment correlation formula. The validity test results show that all values $r_{\text {count }}>r_{\text {tabel }}$. This means that all items on the instructional leadership variable, organizational culture, and teacher performance were valid. Alpha Cronbach formula was used to measure the instrument reliability. Then, based on the calculation, it was found that the instrument was reliable. The result of the reliability test is presented in Table 2 below. 
Table 2. The Result of Reliability Test

\begin{tabular}{cccc}
\hline No. & Variable & Cronbach's Alpha Value & Status \\
\hline 1 & $\mathrm{X} 1$ & 0.968 & Reliable \\
2 & $\mathrm{X} 2$ & 0.979 & Reliable \\
3 & $\mathrm{Y}$ & 0.978 & Reliable \\
\hline
\end{tabular}

\subsection{Data analysis technique}

This study employed the simple regression and multiple regression data analysis techniques. Simple regression technique is based on the functional or causal relationship of one independent variable with another dependent variable in which its coefficient of determination is tried to be found $\left(R^{2}\right)$ [39], [40]. The value $\left(R^{2}\right)$ was determined by the square of the $r$ value. The results $\left(\mathrm{R}^{2}\right)$ were then multiplied by $100 \%$ to determine the amount of the contribution of the influence of the dependent variable to the independent [39].

Hypothesis testing was conducted using the multiple regression analysis technique and determination coefficient through several stages. Firstly, the regression line equation was determined Secondly, the a1 (predictor coefficient of X1) value was calculated using this formula $\sum x_{1} y=a_{1} \sum x_{1}^{2}+a_{2} \sum x_{1} x_{1}$, and the value of $\mathrm{a}_{2}$ (predictor coefficient of X2) was calculated using this formula $\sum x_{2} y=a_{1} \sum x_{2}+a_{2} \sum x_{2}^{2}$. At last, the determinant coefficient $\left(R^{2}\right)$ of the (R) square correlation between $\mathrm{Y}$ and $X_{1} X_{2}$ was calculated using the formula below.

$$
R_{y(1,2)}=\sqrt{\frac{a_{1} \sum x_{1} y+a_{2} \sum x_{2} y}{\sum y^{2}}}
$$

The last step was determining the significance using the $\mathrm{F}$ test below.

$$
F_{\text {reg }}=\frac{R^{2}(n-m-1)}{m\left(1-R^{2}\right)}
$$

If the value of $F_{\text {reg }}\left(\mathrm{F}_{\text {count }}\right)$ is higher than $\mathrm{F}_{\text {table, }}$, there is a significant effect of the independent variable on the dependent variable.

\subsection{Prerequisite Test Analysis}

\subsubsection{Normality test}

The normality test was done to ensure that the data were normally distributed. The analysis in this study employed the Kolmogrov-Smirnov K-S test. If the probability value is higher than 0.05 , the population distribution is normal, and if the probability is lower than 0.05 , the population is not normally distributed [41]. The results of the normality test are presented in Table 4 below.

Table 4. Normality Test Results

\begin{tabular}{lccc}
\hline & $\begin{array}{c}\text { Principal's Instructional Leadership } \\
\text { Variables }\end{array}$ & $\begin{array}{c}\text { Organizational Culture } \\
\text { Variables }\end{array}$ & $\begin{array}{c}\text { Teachers' } \\
\text { Performance } \\
\text { Variables }\end{array}$ \\
\hline $\begin{array}{l}\text { Asymp. Sig. } \\
\text { (2-tailed) }\end{array}$ & 0,831 & 0,903 & 0,405 \\
\hline
\end{tabular}


This result shows that three variables in this study have Asymp.Sig $>0.05$. This means that the data are in the normal distribution.

\subsubsection{Linearity Test}

A linearity test was used to test the correlation between the independent variable and the

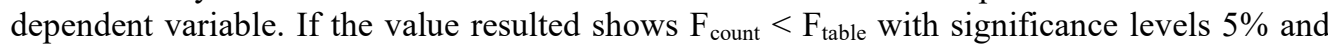
$1 \%$, there is a linear correlation. The formula and calculation are presented below [39].

$$
\begin{aligned}
& \qquad F=\frac{s_{r e g}^{2}}{s_{\text {sis }}^{2}}\left(F_{\text {count }}\right) \\
& \text { Information: } \\
& F \quad=\mathrm{F}_{\text {count }} \\
& S_{\text {reg }}^{2}=\text { regression variation } \\
& s_{\text {sis }}^{2}=\text { remaining variation }
\end{aligned}
$$

The result of the calculation is presented in Table 5 below:

Table 5. Linearity Test Results

\begin{tabular}{lc}
\hline Variables & Sig. \\
\hline Instructional Leadership*Teachers' Performance & 0,873 \\
Organizational Culture*Teachers' Performance & 0,818 \\
\hline
\end{tabular}

The result shows that all variables have significance values higher than $5 \%$. This means that all variables have a linear correlation.

\subsubsection{Multicollinearity test}

This study employed a Variance Inflation Factor (VIF) equation to test multicollinearity. This test aimed to determine whether there was a correlation between independent variables. A good regression model should show no correlation. Multicollinearity refers to the Tolerance value $>0.10$ or equal to VIF $<10$ [42]. The result of the calculation is presented in Table 6 below.

Table 6. Multicollinearity Test Results

\begin{tabular}{llll}
\hline Variable & Tolerance & VIF & Status \\
\hline Principal Instructional Leadership & 0,212 & 4,722 & Not Multicollinear \\
Organizational culture & 0,212 & 4,722 & Not Multicollinear \\
\hline
\end{tabular}

Based on the test result, there is no multicollinearity. 


\section{Results and Discussion}

\subsection{Regression Test Results}

Table 7.Simple Regression Test Results of Hypothesis 1

\begin{tabular}{|c|c|c|c|c|c|c|c|}
\hline $\begin{array}{l}\text { Source } \\
\text { Constants }\end{array}$ & of & $\begin{array}{l}\text { Coefficient } \\
(\mathrm{K}=-33,794)\end{array}$ & $\mathrm{R}$ & $\mathrm{R}^{2}$ & $\mathrm{~F}$ & Sig & Status \\
\hline $\begin{array}{l}\text { Principal } \\
\text { Instructional } \\
\text { Leadership }\end{array}$ & & $\mathrm{a}=0,870$ &, $908^{a}$ & ,825 & 1142,369 & ,000 & $\mathrm{Ha}_{1}$ accepted \\
\hline
\end{tabular}

Table 8.Simple Regression Test Results of Hypothesis 2

\begin{tabular}{lllllll}
\hline $\begin{array}{l}\text { Source of } \begin{array}{l}\text { Coefficient } \\
\text { Constants }\end{array} \\
(\mathrm{K}=-58,385)\end{array}$ & $\mathrm{R}$ & $\mathrm{R}^{2}$ & $\mathrm{~F}$ & $\mathrm{Sig}$ & Status \\
\hline $\begin{array}{l}\text { Organizational } \\
\text { Culture }\end{array}$ & $\mathrm{a}=0,810$ &, $896^{\mathrm{a}}$ &, 802 & 981,357 &, 000 & $\mathrm{Ha}_{2}$ accepted \\
\hline
\end{tabular}

Table 9. Multiple Regression Test Results of Hypothesis 3

\begin{tabular}{llllll}
\hline Source of Constants & Coefficient & $\mathrm{R}$ & $\mathrm{R}^{2}$ & $\mathrm{t}_{\text {count }}$ & $\mathrm{S}$ Sig \\
& & & & & \\
\hline Principal Instructional Leadership & $\mathrm{a}=0,512$ & 0,929 & & 10,30 & \\
& & $\mathrm{a}$ & 0,863 & 9 & 0,000 \\
& $\mathrm{a}=0,381$ & & & 8,117 & \\
Organizational culture & $(\mathrm{K}=-55,624)$ & & & & \\
Constants & 757,272 & & & & \\
$\mathrm{~F}_{\text {count }}$ & 0,862 & & & & \\
Adjusted $\mathrm{R}^{2}$ & & & & \\
\hline
\end{tabular}

\subsection{Dominant Factors}

Predictor contribution is the elaboration of the amount of the independent variable influence on the dependent variable in percentage. The contribution of predictors is categorized into two, namely effective contribution (SE) and relative contribution (SR). Effective contribution (SE) is the contribution of independent variables to the dependent variable in the regression analysis. The total number of all SE independent variables is equal to the value of $\mathrm{R}$ square (R2). Relative contribution (SR) indicates the amount of the contribution of the independent variables to the value of squared regression. The total of all SRs from the independent variables is $100 \%$ or equal to 1 . The following table shows the amount of effective and relative contributions from the independent and dependent variables in this study.

Table 10. Effective and Relative Contribution Values

\begin{tabular}{|c|c|c|}
\hline Variabel & $\mathrm{SE}$ & SR \\
\hline Principal Instructional Leadership & $48,6 \%$ & $56,3 \%$ \\
\hline Organizational culture & $37,7 \%$ & $43,7 \%$ \\
\hline Total & $86,3 \%$ & $100 \%$ \\
\hline
\end{tabular}

These results indicate that the effective contribution (SE) of the independent variables in this study is $86.3 \%$. This percentage is obtained from the SE of the instructional leadership variable 
of the principal of $48.6 \%$, and the SE of the organizational culture variable of $37.7 \%$. The remaining $13.7 \%$ is influenced by other factors.

Then, the relative contribution of the principal's instructional leadership is $56.3 \%$, and the contribution of school organizational culture is $43.7 \%$. From the value of the effective contribution (SE) and the relative contribution (SR) in the table, it can be concluded that the instructional leadership variable has a greater contribution to teacher performance than organizational culture does.

\subsection{The Effect of School Principal Instructional Leadership on Teacher Performance.}

The study finds that there is a significant effect of instructional leadership on teacher performance in public senior high schools located in Sleman Regency. The results of this study support the results of previous study conducted by Utari in 2019 [43]. This study is also in line with Wardani who adopts the leadership model developed by Hallinger and Murphy in 1985 . Wardani suggests effective instructional leadership practices, namely: (1) interpreting the vision of the school together with school members and making optimum efforts to realize the visions and missions set, (2) involving stakeholders in education management, (3) supporting learning processes, (4) monitoring the teaching and learning process to be able to deeply understand and be aware of what is going on at the school, (5) acting as a facilitator to find out problems faced by teachers and helping them solve them. Furthermore, it is noted that if the principal does so, the teacher performance will improve [44].

\subsection{The Effect of Organizational Culture on Teacher Performance}

This study finds that the school organization culture has an effect on teacher performance in public senior high schools located in Sleman Regency. The results of this study are in accordance with the research before. The researh show that organizational culture has a strong influence on teacher performance [45][46]. Further, the results of this study show that the contribution of organizational culture to teacher performance is $37.7 \%$. This means that $62.3 \%$ of teacher performance is determined by other factors. The results of this study support experts' views that there are various factors influencing teacher performance, namely salary, facilities and infrastructure, work environment, leadership, motivation, job satisfaction, job design, commitment, participation, etc [2], [3].

\subsection{The Effect of Instructional Leadership and Organizational Culture Simultaneously on Teacher Performance}

The study indicates that there is an influence of instructional leadership and organizational culture on teacher performance in public high schools. The results of this study are in accordance with the research conducted by Sitanggang, Sibuea, and Sitompul in 2017 stating that there is a positive influence of leadership and organizational culture on teacher performance. In this study, the $\mathrm{R} 2$ value is 0.863 . This value shows that teacher performance is influenced by the variables of instructional leadership and school organizational culture by $86.3 \%$. The remaining $13.7 \%$ is influenced by other factors [47].

\section{Conclusions}

The results of this study show that there is a significant effect of instructional leadership on teacher performance in public senior high schools located in Sleman Regency (48,6\%). There is a significant effect of organization culture on teacher performance in public senior high schools located in Sleman Regency $(37,7 \%)$ There is an influence of instructional leadership 
and organizational culture on teacher performance in public high schools $(86,3 \%)$. Instructional leadership and organizational culture have significant effects on teacher performance both separately and simultaneously. The simultaneous effect of two independent variables on teacher performance is greater. Therefore, this study suggests that instructional leadership should be performed along with the development of conducive school culture in order to improve effectively the quality of teaching-learning processes.

Acknowledgment. I dedicate this research to Yogyakarta State University, and principals of State Senior High Schools in Sleman Regency.

\section{References}

[1] Mulyasa, E. Manajemen dan Kepemimpinan Kepala Sekolah. Jakarta: Bumi Aksara, 2013.

[2] Barnawi dan Arifin M., Instrumen Pembinaan, Peningkatan, \& Penilaian Kinerja Guru Profesional. Yogyakarta: Ar-Ruzz Media, 2014.

[3] Sudarmanto, Kinerja dan Pengembangan Kompetensi SDM Teori, Dimensi Pengukuran, dan Implementasi dalam Organisasi. Yogyakarta: Pustaka Pelajar, 2009.

[4] Vermeulen, M., Van Acker, F., Kreijns, and van Buuren. Does transformational leadership encourage teachers' use of digital learning materials. Educ. Manag. Adm. Leadersh. 2015; vol. 43 (6): pp. 1006-1025.

[5] Bush, T. Instructional Leadership in Centralized Contexts. Educ. Manag. Adm. Leadersh.2014; vol. 42 (1): pp. 3-5.

[6] Hallinger, P. Leading educational change: Reflections on the practice of instructional and transformational leadership. Cambridge J. Educ. 2003; vol. 33 (3): pp. 329-351.

[7] Hallinger, P. Instructional Leadership and the School Principal: A Passing Fancy that Refuses to Fade Away. Leadersh. Policy Sch.2005; vol. 4 (3): pp. 221-239.

[8] Hallinger, P and Heck, R. H. Exploring the Principal's Contribution to School Effectiveness: 1980-1995. School Effectiveness and School Improvement. 1998. vol. 9 (2): pp. 157-191.

[9] Sukmawati, C and Herawan, E. Kepemimpinan Instruksional Kepala Sekolah, Komitmen Guru Dan Mutu Kinerja Mengajar Guru. J. Adm. Pendidik..2016. vol. 23 (2).

[10] Fadhilah and Fahmi, C. N. Pengaruh Budaya Organisasi Terhadap Kinerja Guru Pada Sekolah Menengah Atas di Kabupaten Aceh Besar. J. Semin. Nas. II USM. 2017; vol. 11 no. (1): pp. 213-217.

[11] Fahmi,I Manajemen Kinerja dan Teori Aplikasi. Bandung: Alfabeta, 2013.

[12] Torang, S. Organisasi dan Manajemen (Perilaku Struktur, Budaya dan Perubahan Organisasi). Bandung: Alfabeta, 2013.

[13] Sutrisno, E. Budaya Organisasi. Jakarta: Kencana, 2013.

[14] Nawawi, H. Manajemen Sumber Daya. Yogyakarta: Gajah Mada University Press, 2016.

[15] Mangkunegara, A. P. Manajemen Sumber Daya Manusia Perusahaan. Bandung: PT Remaja Rosdakarya Bandung, 2007.

[16] Yuliejantiningsih, Y. Hubungan Iklim Sekolah, Beban Tugas, Motivasi Berprestasi, Dan Kepuasan Kerja Guru Dengan Kinerja Guru Sd. 2012.

[17] Sa'ud, U.S. Pengembangan Profesi Guru. Bandung: Alfabeta, 2013.

[18] Bush, T. Leadership and management development in education. London: SAGE Publications Inc., 2008.

[19] Bush, T. Instructional leadership and leadership for learning: global and South African perspectives. Educ. as Chang.2014; vol. 17 no (1): 234-255

[20] Yukl, G. Kepemimpinan dalam Organisasi:Edisi Kelima. Jakarta: PT Indeks, 2010.

[21] Northouse, P. Introduction to leadership : concepts and practice, Second edi. Thousand Oaks, CA: SAGE Publications Inc., 2012.

[22] HOY, W.K. and MISKEL, C. G. Educational Administration: Theory, Research, and Practice, 
Ninth Edit. New York: McGraw-Hill, 2013.

[23] Hallinger, P and Murphy, J. Assessing the Instructional Management Behavior of Principals. Elem. Sch. J. 1985; vol. 86 (2): pp. 217-247

[24] Hallinger P., Wang, W.-C. and P. Hallinger. The Evolution of Instructional Leadership in Assessing Instructional Leadership with the Principal Instructional Management Rating Scale. Springer International Publishing. 2015; Vol. 3 (2) pp. 1-23.

[25] Hallinger,P., Wang, W.-C. and Chen. C.-W. Assessing the Measurement Properties of the Principal Instructional Management Rating Scale. Educ. Adm. Q.2013; vol. 49 (2): pp. 272-309

[26] Hallinger, $P$ and Lee, M. Mapping instructional leadership in Thailand: Has education reform impacted principal practice?. Educ. Manag. Adm. Leadersh. 2014 vol. 42 (1): pp. 6-29

[27] Gawlik, M. Instructional leadership and the charter school principal. Sch. Leadersh. Manag.2018; vol. 38 (5): pp. 539-565.

[28] Pan, H. L. W. Nyeu, F. Y. and Chen, J. S. Principal instructional leadership in taiwan: Lessons from two decades of research. J. Educ. Adm.2015; vol. 53 (4): pp. 492-511,

[29] Hallinger, P., Walker, A. D. Nguyen, T. H. Truong, T. and Nguyen. T. T. Perspectives on principal instructional leadership in Vietnam: a preliminary model. J. Educ. Adm.2017; vol. 55 (2): pp. 222-239.

[30] Nguyen, D. T., Ng, D. and Yap. P. S. Instructional leadership structure in Singapore: a coexistence of hierarchy and heterarchy. J. Educ. Adm.2017; vol. 55 (2): pp. 147-167

[31] Hallinger, P. Hosseingholizadeh, R. Hashemi, N. and Kouhsari M.. Do beliefs make a difference? Exploring how principal self-efficacy and instructional leadership impact teacher efficacy and commitment in Iran. Educ. Manag. Adm. Leadersh. 2018; vol. 46 (5) pp. 800-819

[32] Kreitner, R. and Kinicki, A. Organizational Behaviour. New York: McGraw-Hill, 2010.

[33] Kusdi, Budaya Organisasi : Teori, Penelitian, dan Praktik. Jakarta: Salemba Empat, 2011.

[34] Lestari, H., Wijaya, A. R and Subayo. Pengukuran Budaya Organisasi Pada Industri Minuman Di Jawa Tengah Untuk Meningkatkan Daya Saing Di Era Global. Pros. SNST.2013; Vol. 3 (2): pp. 20-25.

[35] Casida, J. M. “The Relationship of Nurse Managers' Leadership Styles and Nursing Unit Organizational Culture in Acute Care Hospitals in New Jersey,” Seton Hall University Dissertations and Theses (ETDs). 1732., 2007.

[36] Sobirin, A. Budaya Organisasi Pengertian, Makna dan Aplikasinya Dalam Kehidupan Organisasi. Yogyakarta: IBPP STIM YKPN, 2007.

[37] Zwaan, L. "Assessing Organisational Culture In A Private Hospital In The Western Cape," University of the Western Cape, 2006.

[38] Sukmadinata, N. S. Metode Penelitian Pendidikan. Bandung: Remaja Rosdakarya, 2015.

[39] Sugiyono, Metode Penelitian Pendidikan (Pendekatan Kuantitatif, Kualitatif, dan R\&D). Bandung: Alfabeta, 2016.

[40] Muhson, A. Pedoman Praktikum Analisis Statistik (Edisi Ketiga). Yogyakarta: Fakultas Ekonomi Universitas Negeri Yogyakarta, 2019.

[41] Santoso, S. SPSS Versi 11.5 Cetakan Kedua. Jakarta: Gramedia, 2002.

[42] Ghozali, I. Aplikasi analisis multivariete dengan program IBM SPSS 23, Cet. VIII. Badan Penerbit Universitas Diponegoro, 2016.

[43] Utari, N. "Pengaruh Kepemimpinan Instruksional Kepala Sekolah Terhadap Kinerja Guru Di Smp Negeri 1 Kalukku Kab. Mamuju," UIN Alauddin Makasar, 2019.

[44] Wardani, D. K and Indriayu, M. "Kepemimpinan Pembelajaran Kepala Sekolah Untuk Meningkatkan Profesionalisme Guru Menghadapi Masyarakat Ekonomi Asean,” Jun. 2015.

[45] Herawati, N., Juwita, P. and Sasongko, R. N. Pengaruh Kepemimpinan Kepala Sekolah dan Budaya Organisasi terhadap Kinerja Guru SMPN se-Kecamatan Kota Manna Kabupaten Bengkulu Selatan. Manajer Pendidik.2017; vol. 11 (5): pp. 410-413.

[46] Febriantina, S., Lutfiani, F. N. and Zein, N. Pengaruh Budaya Organisasi Terhadap Kinerja Guru the Influence of Organizational Culture on Teacher Performance. Tadbir Muwahhid. 2018; vol. 2 (2): 23-33.

[47] Sitanggang, S., Sibuea, A. M. and Sitompul, H. Pengaruh Kepemimpinan Pembelajaran, 
Budaya Organisasi dan Kepuasan Kerja Guru Terhadap Kinerja Guru SMP Negeri Kecamatan Sipoholon Kabupaten Tapanuli Utara. J. TABULARASA PPS UNIMED. 2017; vol. 14 (2): pp. 146-156. 